\title{
Gap Junction-mediated Cell-to-Cell Communication in Bovine and Human Adrenal Cells. A Process whereby Cells Increase Their Responsiveness to Physiological Corticotropin Concentrations
}

\author{
Y. Munari-Silem, ${ }^{\star}$ M.C. Lebrethon, ${ }^{\star}$ I. Morand, ${ }^{\star}$ B. Rousset, ${ }^{\star}$ and J.M. Saez ${ }^{\star}$ \\ * INSERM U369, Faculté de Médecine Alexis Carrel, 69372-Lyon Cedex 08, France; and ${ }^{\ddagger}$ INSERM U307, Hôpital Debrousse, \\ 69322-Lyon Cedex 05, France
}

\begin{abstract}
We have studied the role of gap junction-mediated intercellular communication on the steroidogenic response of bovine (BAC) and human (HAC) adrenal fasciculo-reticularis cells in culture to corticotropin (ACTH). Indirect immunofluorescence analyses showed that intact human and bovine adreno-cortical tissue as well as $\mathrm{HAC}$ and $\mathrm{BAC}$ in culture expressed the gap junction protein connexin 43 (also termed $\alpha 1$ connexin). Both HAC and BAC were functionally coupled through gap junctions as demonstrated by microinjection of a low molecular mass fluorescent probe, Lucifer yellow. The cell-to-cell transfer of the probe was blocked by $18 \alpha$-glycyrrhetinic acid (GA), an inhibitor of gap junctionmediated intercellular communication. GA markedly decreased the steroidogenic response (cortisol production) of both HAC and BAC to low (10 pM) but not to high ( $5 \mathrm{nM}$ ) concentrations of ACTH. GA had no inhibitory effect on the steroidogenic response to $8 \mathrm{Br}$-cAMP (at either low or high concentrations) and did neither modify the binding of ${ }^{125}$ I-ACTH to its receptor nor the ACTH-induced cAMP production. BAC cultured at high or low cell densities $\mathbf{( 2 . 4}$ $\times 10^{5}$ vs. $0.24 \times 10^{5}$ cells $/ \mathrm{cm}^{2}$ ) exhibited distinct levels of intercellular communication and were differently responsive to sub-maximal ACTH concentrations. The ACTH ED S0 $_{50}$ values for cortisol production were $8.5 \pm 1.3$ and $45 \pm 14 \mathrm{pM}$ $(P<0.02)$ for BAC cultured at high and low density, respectively. In the presence of GA, there was a shift of the ACTH concentration-response curves in the two culture conditions. The ACTH ED S0 $_{50}$ high density and low density cultured BAC increased 25- and 5-fold, respectively, and became similar $(220 \pm 90$ and $250 \pm 120 \mathrm{pM})$. These results demonstrate that gap junction-mediated communication between hormone-responsive and nonresponsive cells is one mechanism by which adrenal cells increase their responsiveness to low ACTH concentrations. (J. Clin. Invest. 1995. 95:1429-1439.) Key words: gap junctions • adrenal cells • cell-to-cell communication $\cdot$ corticotropin $\cdot$ steroidogenesis
\end{abstract}

Address correspondence to Dr. Bernard Rousset, INSERM U369, Faculté de Médecine Alexis Carrel, 69372-Lyon Cedex 08, France. Phone: 78-77-87-45; FAX: 78-77-87-36.

Received for publication 30 March 1994 and in revised form 7 November 1994.

J. Clin. Invest.

(c) The American Society for Clinical Investigation, Inc.

$0021-9738 / 95 / 04 / 1429 / 11 \quad \$ 2.00$

Volume 95, April 1995, 1429-1439

\section{Introduction}

The biological response of an organ or a tissue to a stimulus is, at any time, the result of the activity of numerous cells that adjust their functioning to provide an integrated response adapted to the needs of the organism. Cells are therefore expected to adapt their individual responsiveness to physiological modifications of their environment in a coordinated way. Coordination is primarily achieved by extracellular signals which act on individual cells expressing the same specific receptors. Another mechanism by which cells could coordinate and sometimes synchronize their responses is the direct cell-to-cell communication through specialized intercellular junctions named gap junctions (GJ). ${ }^{1}$ In most organs and tissues, cells (of the same type or more exceptionally of distinct types) can exchange molecules of low molecular mass $(<1,000 \mathrm{D})$, naturally dissolved in their cytoplasm, through GJ $(1,2)$. By allowing the cell-to-cell transfer of informative molecules, GJ are involved in the control of cell growth, differentiation and metabolic cooperation (for reviews see references 3-8). GJ channels between adjacent cells can be open or closed; the transition from one state to the other is a regulated process $(7,8)$. GJ are known to be permeable to inositol $1,4,5$ triphosphate and calcium ions (9-14) and to cyclic AMP (15-18). It has been elegantly demonstrated that cells that do not respond to a given external signal could be committed to respond by receiving the adequate second messenger from neighboring responsive cells with which they are coupled through GJ (16-18). These data show how gap junctional communication can participate in the coordination of cell responses. There is now need to define physiological situations or functional circumstances in which GJ-mediated cell-to-cell transfer of second messengers actually participates in the determination of the overall response of a cell population to an external signal.

We have used two well-characterized cell culture systems, adrenocortical cells of bovine or human origin in primary culture that produce cortisol in response to corticotropin (ACTH) via the cAMP pathway $(19,20)$ and a method of analysis of GJ-mediated cell-to-cell communication by microinjection of a fluorescent probe (Lucifer yellow) to examine the functional impact of gap junctional communication. First, we examined whether compounds known to cause GJ closure such as $18 \alpha$ glycyrrhetinic acid (GA) $(21,22)$ or octanol $(23,24)$, could

1. Abbreviations used in this paper: BAC, bovine adrenal fasciculatareticularis cells; connexin43: $\alpha_{1}$ connexin, $43-\mathrm{kD}$ cardiac gap junction protein; connexin32: $\beta_{1}$ connexin, 32-kD liver gap junction protein; $\mathrm{F}_{12} / \mathrm{DME}$, Ham's $\mathrm{F}_{12} /$ Dulbecco Modified Eagle's Medium; GA, $18 \alpha$ glycyrrhetinic acid; GJ, gap junction; HAC, human adrenal fasciculatareticularis cells 
alter the secretory response of adrenal cell populations to ACTH. We then analyzed the extent that the hormone concentration-response relationship could depend on the level of GJ coupling within a cell population. Variations of GJ coupling were obtained by culturing cells at different densities and by applying a GJ inhibitor. Our results suggest that cell-to-cell communication determines the responsiveness of adrenocortical cells to low ACTH concentrations. We have found that the concentration of ACTH required to obtain the half-maximum cortisol production could vary up to 25 -fold depending on the level of cell-to-cell coupling within the cell population. These results provide at least one explanation for the known discrepancy between the $K_{\mathrm{d}}$ value for the interaction of ACTH with its receptor and the ACTH concentrations active on steroidogenesis both in physiological conditions $(25,26)$ and in Cushing's disease (27).

\section{Methods}

Cell culture. Bovine adrenal cells (BAC) were isolated and cultured as previously described (28). Briefly, bovine adrenal glands were collected from a local slaughterhouse, dissected, freed of fat, and sliced with a Stadie-Riggs microtome delivering slices of $0.5 \mathrm{~mm}$. The first slice containing zona glomerulosa was discarded, whereas the second and third slices were used for preparation of fasciculata cells. Dispersed cells were obtained by four successive 20-min treatments with trypsin (0.19\%) in Ham's F-12/Dulbecco's modified Eagle's medium (F12/ DME) (1:1) containing gentamycin $(20 \mu \mathrm{g} / \mathrm{ml})$, penicillin (100 U/ $\mathrm{ml})$, streptomycin $(0.1 \mathrm{mg} / \mathrm{ml})$ nystatin $(100 \mathrm{U} / \mathrm{ml}), 14 \mathrm{mM} \mathrm{NaHCO}$, and $15 \mathrm{mM}$ Hepes, $\mathrm{pH}$ 7.4. The cells were harvested, washed and placed in a growth medium composed of F12/DME containing insulin ( $10 \mu \mathrm{g} /$ $\mathrm{ml})$, transferrin $(10 \mu \mathrm{g} / \mathrm{ml})$, vitamin $\mathrm{C}(0.1 \mathrm{mM})$ and fetal calf serum (1\%). The next day, the medium was removed and replaced by the same medium without serum. Adult human adrenals were obtained from patients in cerebral death at the same time that the kidneys were removed for transplantation. Although it is likely that patients with cerebral death have marked changes in endocrine function, the basal cortisol secretion of both HAC and BAC was low after 2 to $3 \mathrm{~d}$ in culture, suggesting a "normalization" of adrenal cell activities. This protocol was approved by the ethical committee of the Hospices Civils de Lyon (France). After removal of the major part of the medulla, the zona fasciculata-reticularis was separated from the capsula and used for cell preparation. In preliminary experiments, attempts were made to isolate human adrenal cells (HAC) with the trypsin digestion method used for BAC dispersion. The yield was very low (2-4 × $10^{6}$ cells/adrenal), and more than $50 \%$ of cells were not viable. HAC were dispersed by two successive $20 \mathrm{~min}$ treatments with collagenase $(1 \mathrm{mg} / \mathrm{ml})$ and DNase $(0.1 \mathrm{mg} / \mathrm{ml})$ in $\mathrm{F} 12 /$ DME medium, supplemented with $\mathrm{NaHCO}_{3}(14 \mathrm{mM})$ and Hepes (10 $\mathrm{mM}$ ) and antibiotics (the same mixture as that used for BAC dispersion). The yield was greatly improved $\left(30-35 \times 10^{6}\right.$ cells $/$ adrenal $)$, and only $10 \%$ of cells were not viable. Isolated cells were then seeded in Petri dishes in F12/DME containing 10\% fetal serum plus insulin $(10 \mu \mathrm{g} / \mathrm{ml})$, transferrin $(10 \mu \mathrm{g} / \mathrm{ml})$ and vitamin $\mathrm{C}(0.1 \mathrm{mM})$. After 24 $h$, the medium was changed and replaced by the same medium without serum. For both BAC and HAC, plating efficiency varied between 70 and $80 \%$ and, in our culture conditions, cell multiplication was negligible. The precise number of cells used in each experimental protocol was determined at the end of the experiments using a Coulter counter.

Measurements of cell activities. For both cell culture types, the medium was changed every two days. The inhibitors of GJ were added $10 \mathrm{~min}$ before the effectors. cAMP was measured in the medium after $1 \mathrm{~h}$ of incubation, at which time $>80 \%$ of the total cAMP was extracellular. cAMP accumulation in the medium is related to the concentration of ACTH used (29-31). Medium cortisol was measured after a 2-h incubation period because a linear increase has been observed during this period after ACTH stimulation $(30,32)$. Cortisol and cAMP were measured by specific radioimmunoassays as previously described (28). The binding of ${ }^{125} \mathrm{I}$-labeled human $\left(\mathrm{Tyr}^{23}\right.$ ) ACTH (1-39) (Amersham, Les Ulis, France; specific activity: $74 \mathrm{TBq} / \mathrm{nmol}$ ) to BAC was performed as described (31).

Assessment of direct cell-to-cell communication. Gap junction-mediated intercellular communication was assayed by direct cell-to-cell transfer of a low Mr fluorescent dye: Lucifer yellow, a probe originally used by Stewart (33). Lucifer yellow (Sigma Chemical Co., St. Louis), 5\% (wt/vol) in $0.3 \mathrm{M} \mathrm{LiCl}$, was microinjected into the cytoplasm, under nitrogen pressure applied for $0.1-0.3 \mathrm{~s}$ using a micromanipulator 5170 and a microinjector 5242 from Eppendorf (Hamburg, Germany), installed on an Axiovert $35 \mathrm{M}$ inverted microscope from Zeiss (Oberkochen, Germany). Microinjections were performed using glass micropipettes (Femptotips from Eppendorf) in cultured cells maintained at $37^{\circ} \mathrm{C}$ using a control heating unit (TRZ 3700 from Zeiss). Lucifer yellow distribution was visualized using the filter combination BP 395440/LP 470 from Zeiss. Fluorescence images of probe distribution were taken within 5 min after microinjection using either 400 ASA T-MAX Kodak films (Eastman Kodak Co., Rochester, NY) or a SIT camera (Lhesa electronique, Cergy-Pontoise, France) coupled to an image processing system (Sapphire from Quantel, Montigny-le-Bretonneux, France) and stored on a Bernoulli box.

Immunofluorescence labeling. Cultured cells were washed with the culture medium without serum and fixed with $4 \%$ paraformaldehyde in PBS for $30 \mathrm{~min}$ in Petri dishes. The affinity-purified anti-connexin antibodies used at the concentration of $3 \mu \mathrm{g} / \mathrm{ml}$ in PBS containing $1 \mathrm{mg} / \mathrm{ml} \mathrm{BSA}$ were applied onto fixed cells overnight at $4^{\circ} \mathrm{C}$. Hen anticonnexin 32 antibodies and rabbit anti-connexin 43 antibodies were produced against synthetic peptides corresponding to residues 266-282 of rat connexin 32 and to residues $314-322$ of rat connexin $43(34,35)$, respectively. Immunodetection of hen IgGs was achieved using affinitypurified goat anti-hen IgG $(\mathrm{H}+\mathrm{L})$ coupled to fluorescein from KPL Laboratories (Gaithersburg, MD). Rabbit IgGs were detected using $F(a b) 2$ fragments of goat anti-rabbit affinity-purified antibody coupled to fluorescein from Sigma Chemical Co. Fluorescein-conjugated secondary antibodies were applied for $30 \mathrm{~min}$ at room temperature. Cells were mounted in Fluoprep mounting preparation (Biomérieux, France) and examined on an Axiophot microscope from Zeiss. Fluorescence images were recorded using a SIT camera coupled to the Sapphire image processing system, and photomicrographs were made using a video printer UP 5000 (Sony, Japan).

\section{Results}

Inhibition of GJ-mediated intercellular communication in cultured bovine adrenocortical cells $(B A C)$ by $18 \alpha$-glycyrrhetinic acid (GA). BAC cultured at a high concentration of $2.4 \times 10^{5}$ cells $/ \mathrm{cm}^{2}$ formed subconfluent monolayers. Cells had a typical epithelial morphology (Fig.1, $a$ and $d$ ). Monolayer cells were tested for their ability to communicate via GJ. Lucifer yellow microinjected into the cytoplasm of a cell was detected within seconds in those cells surrounding the injected one (Fig.1, $b$ and $c$ ). By microinjecting a large number of BAC, we observed that the level of intercellular communication was rather heterogeneous within the cell population. The number of dye-coupled cells varied from 2 to about 20 , and the average number of communicating cells per injection was $8.5 \pm 1$ (mean \pm SEM). Furthermore, $\sim 20 \%$ of cells which were microinjected did not communicate with any neighboring cells. The effects of $18 \alpha$ glycyrrhetinic acid (GA) on GJ-mediated intercellular communication in BAC are illustrated in Fig. 1, $d-f$ and quantified in Fig. 2. Treatment of BAC with $10 \mu \mathrm{M}$ GA caused a timedependent inhibition of cell-to-cell transfer of Lucifer yellow. A marked reduction in cell coupling was already evident after 5 min (Fig. 2). A complete inhibition of cell-to-cell communi- 

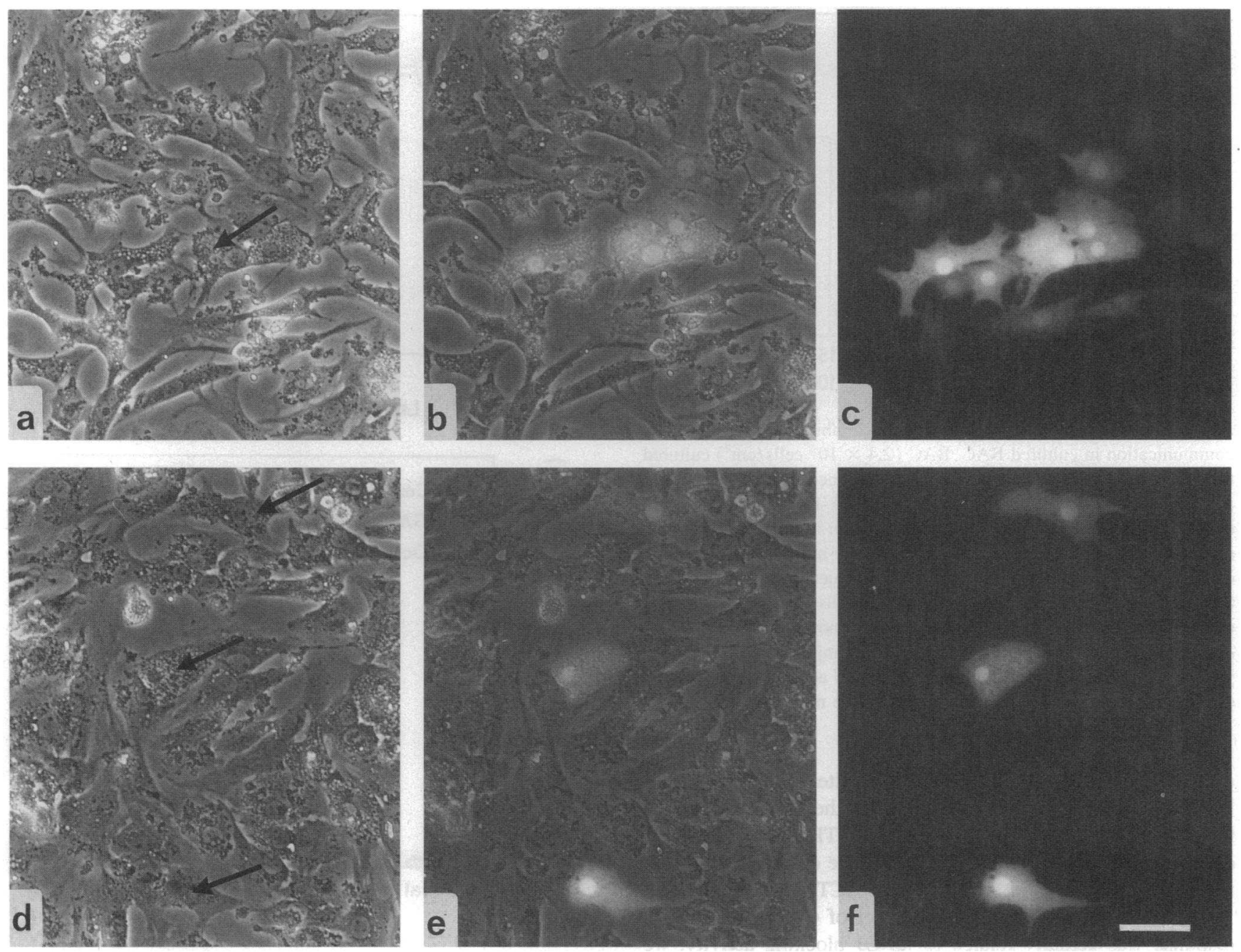

Figure 1. Intercellular communication between BAC in primary culture. Inhibition by GA of GJ-mediated intercellular communication visualized by the cell-to-cell diffusion of Lucifer yellow. BAC $\left(2.4 \times 10^{5}\right.$ cells $\left./ \mathrm{cm}^{2}\right)$ were cultured for $5 \mathrm{~d}$ and incubated without $(a-c)$ or with $(d-f) 10$ $\mu \mathrm{M} \mathrm{GA}$ for $30 \mathrm{~min}$ at $37^{\circ} \mathrm{C}$. Lucifer yellow was then microinjected into the cytoplasm of one, two, or three distant cells (identified by arrows on the phase contrast micrographs). The distribution of the fluorescent dye was examined $5 \mathrm{~min}$ after microinjection. The panels from the left to the right correspond to the phase contrast ( $a$ and $d)$, phase contrast plus fluorescence ( $b$ and $e$ ) and fluorescence $(c$ and $f$ ) images of the same field. Lucifer yellow introduced in one cell of the untreated BAC monolayer $(a)$ diffused in numerous adjacent cells $(b$ and $c)$. In contrast, none of the microinjected cells $(d)$ of the GA-treated BAC monolayer transferred the dye to neighboring cells $(e$ and $f)$. Bar, $50 \mu \mathrm{m}$.

cation was obtained after 30 min of incubation; Lucifer yellow remained located in the microinjected cells in $100 \%$ of the cases (Fig.1 $f$ ). When GA was used at lower concentrations (between 1 and $10 \mu \mathrm{M})$, longer incubation times were required to abolish GJ-mediated intercellular communication. A complete inhibition was obtained after a 1 h-incubation of BAC with 5 $\mu \mathrm{M}$ GA.

The GA-induced inhibition of GJ-mediated cell-to-cell communication influences the steroidogenic response of $B A C$ to $A C T H$. At concentrations $\leqslant 10 \mu \mathrm{M}$, GA did not affect the basal cortisol production by BAC. GA exerted a concentration-dependent inhibitory action on the steroidogenic effects of submaximal concentrations of ACTH, whereas those of $8 \mathrm{Br}$-cAMP were only slightly reduced at $10 \mu \mathrm{M}$ (Fig. $3 \mathrm{~A}$ ). For all subsequent experiments, a GA concentration of $5 \mu \mathrm{M}$ was selected since GJ-mediated cell-to-cell communication was completely inhibited (Fig. 2) and the ACTH-response was reduced 70\%, but the response to $8 \mathrm{Br}$-cAMP was not affected (Fig. $3 \mathrm{~A}$ ).
BAC in culture exhibited a low basal cortisol production which was increased up to 70 -fold in response to maximal concentrations of ACTH or $8 \mathrm{Br}$-cAMP. Results of Fig. $3 \mathrm{~B}$ shows that GA differently affected the secretory response to low (10 pM) and high ( $5 \mathrm{nM})$ ACTH concentrations. GA decreased the cortisol production in response to a submaximal concentration of ACTH ( $10 \mathrm{pM})$ but was without effect on the response to a maximal or saturating concentration of ACTH ( 5 $\mathrm{nM})$. Interestingly, GA treatment did not affect the response of $0.1 \mathrm{mM} 8 \mathrm{Br}$-cAMP in eliciting a submaximal cortisol production or the response of $1 \mathrm{mM} 8 \mathrm{Br}$-cAMP in yielding the maximal cortisol production. Similar results were obtained with another GJ blocker, octanol.

We examined whether GA inhibition of the steroidogenic response to submaximal concentrations of ACTH could be due to drug effects other than that on GJ closure. For instance, we tested whether GA affected the binding of ACTH to its membrane receptors or the ACTH-induced activation of adenylyl 


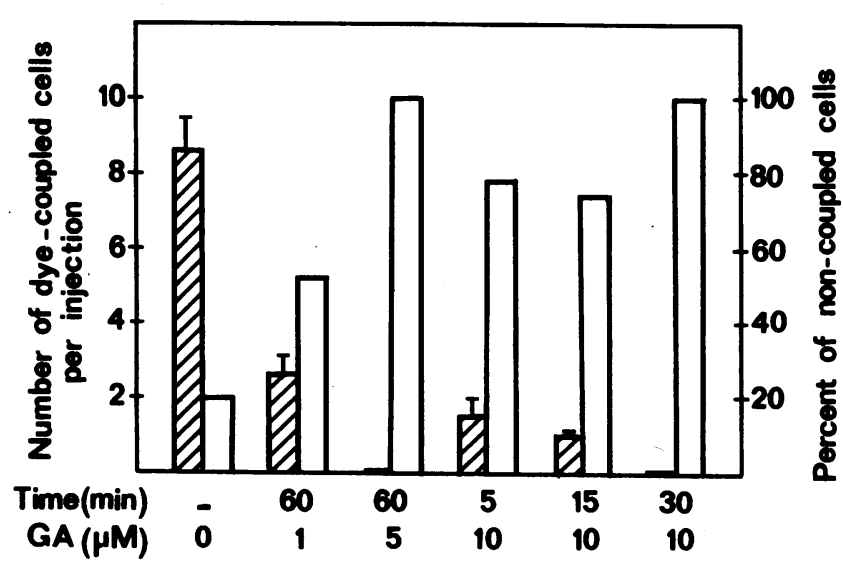

Figure 2. Quantitative analysis of GA-induced inhibition of intercellular communication in cultured BAC. BAC $\left(2.4 \times 10^{5}\right.$ cells $\left./ \mathrm{cm}^{2}\right)$ cultured for $5 \mathrm{~d}$ were incubated with GA at different concentrations for 5-60 min at $37^{\circ} \mathrm{C}$. In each experimental condition, 10-60 randomly selected cells in the Petri dishes were microinjected with Lucifer yellow. The number of fluorescently labeled cells around the microinjected one was determined within 5-15 min after a series of injections; it varied from 0 (uncoupled cell) to up to 20 . The histogram displays two parameters of cell-to-cell communication: the percentage of non-coupled cells (open columns) and the number of coupled cells per injection when Lucifer yellow was transferred from the injected cell to at least one other cell (hatched columns); results are expressed as the mean \pm SEM.

cyclase (Table I). GA ( $5 \mu \mathrm{M})$ neither altered the binding of labeled ${ }^{125} \mathrm{I}-\mathrm{ACTH}$ to BAC, nor modified the cAMP generation in response to either $10 \mathrm{pM}$ or $5 \mathrm{nM} \mathrm{ACTH}$. Under the same experimental conditions, GA decreased the cortisol production in response to low but not to maximal ACTH concentrations.

To further document that the effect of GA on the ACTH response was actually related to its GJ blocking activity, we compared the action of the drug on monolayer cells in Petri dishes having established GJ as shown in Fig. 1 and on corresponding cells in suspension that were collected from Petri dishes and dispersed by a mild trypsin treatment to disrupt cell interactions via GJ. As shown in Fig. 4, the steroidogenic response to $10 \mathrm{pM}$ ACTH was decreased by GA when cells were kept as monolayers but was not affected by GA when cells were dispersed and maintained in suspension. The response to a maximal ACTH concentration ( $10 \mathrm{nM}$ ) was unaffected by the GA treatment in both cell systems. It is noteworthy that a concentration of ACTH of $10 \mathrm{pM}$ which produced about halfmaximum response on monolayer cells only gave a response equal to $30 \%$ of the maximum response on dispersed cells. The dispersed cells did have a lower density of ACTH receptors compared with cultured cells (31) which may have been a consequence of trypsin treatment.

GA also inhibits GJ-mediated cell-to-cell communication and the steroidogenic response to ACTH on human adrenocortical cells $(H A C)$. To further document the general relevance of our findings, the same experiments were performed using HAC in culture. HAC cultured at the same concentration as BAC $\left(2.4 \times 10^{5}\right.$ cells $\left./ \mathrm{cm}^{2}\right)$ did not spread on the Petri dishes but formed cell clusters of various size (Fig. 5, $a$ and $d$ ). After microinjection of Lucifer yellow in one cell or possibly a few cells in a three-dimensional aggregate, there was rapid diffusion of the fluorescent dye to a large number of cells and often into almost all the cells of the cluster (Fig. 5, $B$ and $C$ ). A $30 \mathrm{~min}$
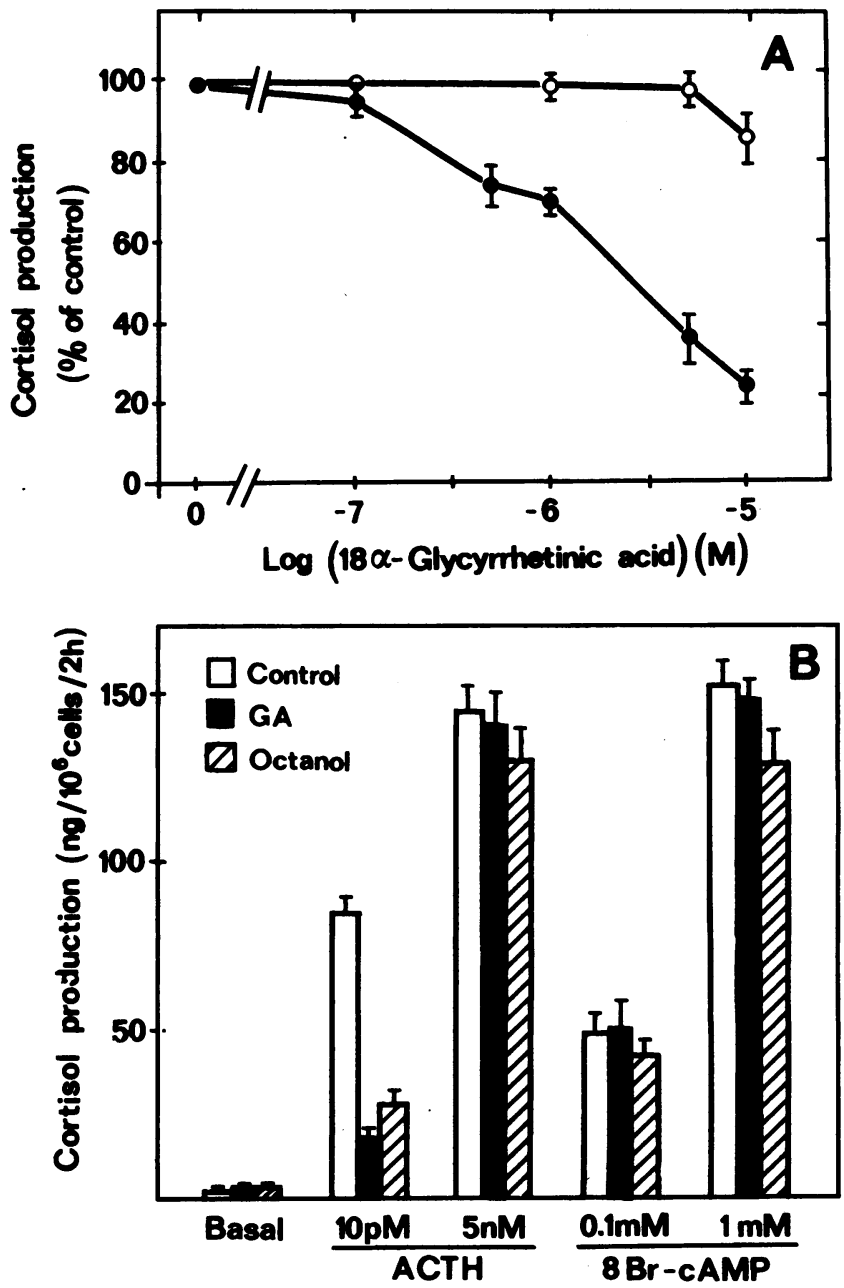

Figure 3. Incidence of the inhibition of GJ-mediated intercellular communication on the ACTH- or $8 \mathrm{Br}$-cAMP-stimulated cortisol production by BAC. $(A)$ Effects of increasing concentrations of GA on ACTH and 8Br-cAMP-induced cortisol production. BAC $\left(2.4 \times 10^{5} \mathrm{cells} / \mathrm{cm}^{2}\right)$ cultured for $5 \mathrm{~d}$ were incubated without or with $10 \mathrm{pM} \mathrm{ACTH}(\bullet)$ or $0.1 \mathrm{mM} 8 \mathrm{Br}$-cAMP $(\mathrm{O})$ in the presence of various concentrations of GA from 0.1 to $10 \mu \mathrm{M}$ for $2 \mathrm{~h}$ at $37^{\circ} \mathrm{C}$. Cortisol was assayed in the medium. GA at all concentrations tested, did not affect the basal cortisol production. Thus, results of the effects of GA on ACTH- or 8Br-cAMPstimulated cortisol production have been expressed as percent of control. Each point and vertical bar represent the mean \pm SEM of triplicate. $(B)$ Effects of GA and octanol on the response of BAC to ACTH or $8 \mathrm{Br}$ cAMP. BAC $\left(2.4 \times 10^{5}\right.$ cells $\left./ \mathrm{cm}^{2}\right)$ cultured for $5 \mathrm{~d}$ were incubated without or with ACTH ( $10 \mathrm{pM}$ or $5 \mathrm{nM})$ or $\mathrm{Br}$-cAMP $(0.1$ or $1 \mathrm{mM})$ in the absence or the presence of $5 \mu \mathrm{M}$ GA or $1 \mathrm{mM}$ octanol. Cortisol was assayed in the incubation medium. Results represent the mean \pm SEM of the values obtained in two separate experiments; each experimental condition was done in quadruplicate. GA and octanol had the same effects; the GJ inhibitors only decreased the response to the submaximal concentration of ACTH.

incubation of HAC with $5 \mu \mathrm{M}$ GA led to a marked inhibition of the cell-to-cell transfer of Lucifer yellow (Fig. 5, $E$ and $F$ ). In almost all cases, few cells displayed fluorescence around the site of microinjection even after a longer period of exposure to GA. This may have been due to the injection of Lucifer yellow into several cells of the clusters and not into a single cell as was possible with the BAC monolayers. As compared with 


\begin{tabular}{|c|c|c|c|c|c|c|}
\hline \multirow[b]{2}{*}{ Effector } & \multicolumn{2}{|c|}{${ }^{125} \mathrm{I}-\mathrm{ACTH}$ bound $\left(\mathrm{cpm} / 10^{6}\right.$ cells) } & \multicolumn{2}{|c|}{ cAMP pmoles $/ 1$ h per $10^{6}$ cells } & \multicolumn{2}{|c|}{$\begin{array}{l}\text { Cortisol production ng/1 h per } 10^{6} \\
\text { cells }\end{array}$} \\
\hline & Control & GA & Control & GA & Control & GA \\
\hline None & $2200 \pm 220$ & $2100 \pm 150$ & $0.6 \pm 0.1$ & $0.8 \pm 0.2$ & $0.9 \pm 0.2$ & $1.4 \pm 0.4$ \\
\hline ACTH $(10 \mathrm{pM})$ & - & - & $4 \pm 0$ & $5 \pm 3$ & $43 \pm 3$ & $8 \pm 2$ \\
\hline ACTH (5 nM) & - & - & $23 \pm 3$ & $21 \pm 4$ & $78 \pm 5$ & $73 \pm 4$ \\
\hline
\end{tabular}

BAC $\left(2.7 \times 10^{5}\right.$ cells $\left./ \mathrm{cm}^{2}\right)$ were cultured for $3 \mathrm{~d}$. For the measurement of ACTH binding, cells were incubated with $80 \mathrm{pM}{ }^{125} \mathrm{I}-\mathrm{ACTH}$ for $1 \mathrm{~h}$ at $37^{\circ} \mathrm{C}$ in the presence or the absence of $5 \mu \mathrm{M}$ GA. Specific binding was measured as previously described (31). Cells were incubated with the indicated concentration of ACTH in the presence or absence of $5 \mu \mathrm{M} \mathrm{GA}$, and the cAMP and cortisol productions were measured after $1 \mathrm{~h}$ of incubation at $37^{\circ} \mathrm{C}(28)$. Results are the mean $\pm S E M$ of two experiments.

BAC, HAC produced about 10 times more cortisol in their basal state: $20-30$ versus $2-3 \mathrm{ng} / 10^{6}$ cells $/ 2 \mathrm{~h}$ for BAC. A 2 -h treatment of HAC with $5 \mu \mathrm{M}$ GA did not alter the basal cortisol release but reduced by $60-70 \%$ the cortisol production in response to $10 \mathrm{pM} \mathrm{ACTH,} \mathrm{a} \mathrm{hormone} \mathrm{concentration} \mathrm{eliciting} \mathrm{the}$ half-maximum steroidogenic response (Fig. 6). The response of HAC to a maximal ACTH concentration ( $5 \mathrm{nM}$ ) as well as the responses to low or maximal $8 \mathrm{Br}$-cAMP concentrations were not affected by the GA treatment. Octanol, $1 \mathrm{mM}$, produced the same effects as GA.

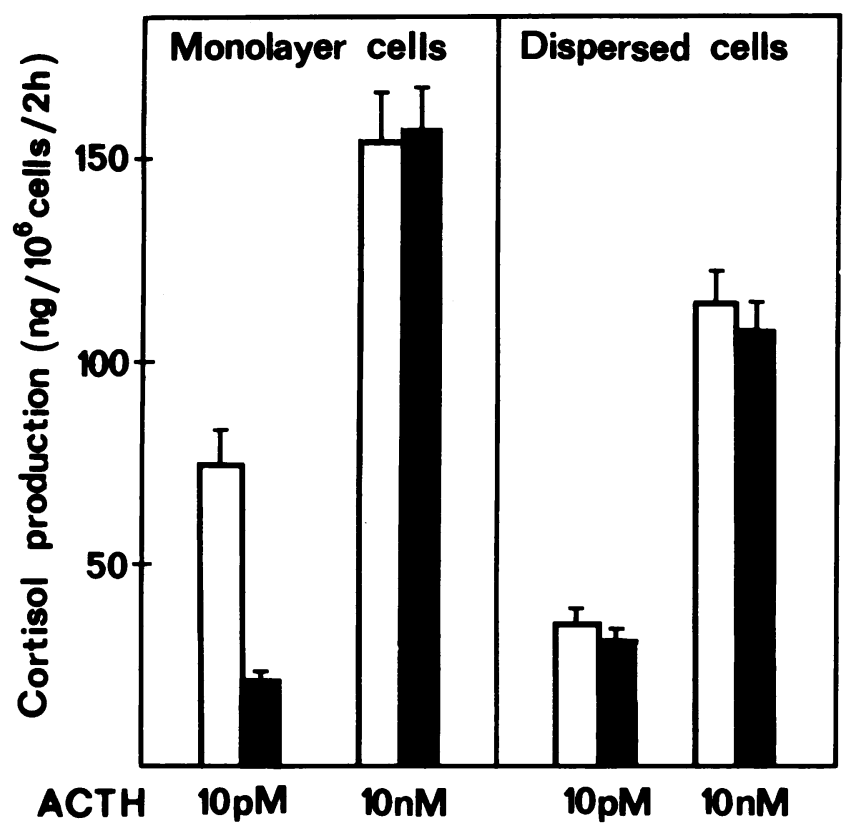

Figure 4. Evidence that the inhibitory effect of GA on the response of BAC to ACTH is related to the GA-induced inhibition of intercellular communication. BAC $\left(3 \times 10^{5} \mathrm{cells} / \mathrm{cm}^{2}\right)$ were cultured for $3 \mathrm{~d}$. Some of the dishes were treated with $0.25 \%$ (wt/vol) trypsin, $1 \mathrm{mM}$ EDTA for $10 \mathrm{~min}$ to detach the cells. For obtaining completely isolated cells, the cell suspension was submitted to repeated pipetting. Cells were then washed several times and suspended in the culture medium. Intact monolayers and corresponding isolated cells were incubated without or with ACTH ( $10 \mathrm{pM}$ or $10 \mathrm{nM})$ in the absence (open columns) or in the presence (closed columns) of $5 \mu \mathrm{M}$ GA for $2 \mathrm{~h}$ at $37^{\circ} \mathrm{C}$. Cortisol was assayed in the medium. Columns and vertical bars represent the mean \pm SEM of triplicate.
Immunodetection of connexin43 in cultured BAC and HAC. GJ were visualized by indirect immunofluorescence in BAC and HAC using antibodies directed against two different GJ proteins, connexin 43 and connexin 32 . Purified anti-connexin 43 antibodies labeled rather large spots distributed along regions of cell-cell contacts in BAC monolayers (Fig. 7, $a$ ). HAC were also positive for connexin 43 . The anti-connexin 43 antibodies labeled a rather large number of small spots grouped in clusters (Fig. $7 \mathrm{c}$ ). Due to the superimposition of HAC, the labeled structures could not be clearly identified. Nevertheless, fluorescence labeling was presumably located between the cells but some labeling of connexin 43 in the cytoplasm cannot be ruled out. Both BAC and HAC were not labeled by connexin 32 antibodies. Similar results were obtained on tissue sections of bovine and human adrenal glands (data not shown).

The responsiveness of $B A C$ to $A C T H$ depends on the level of $G J$-mediated intercellular communication. We performed full ACTH concentration-response studies on monolayer cell preparations that display distinct levels of GJ coupling. Experiments were designed to obtain three different levels of GJ coupling: 1. cells were cultured at high density $\left(2.4 \times 10^{5} \mathrm{cells} / \mathrm{cm}^{2}\right)$ to promote cell-cell interactions and favor GJ coupling, 2. cells were cultured at low density $\left(0.24 \times 10^{5}\right.$ cells $\left./ \mathrm{cm}^{2}\right)$ to make cell contacts scarce and limit GJ coupling and 3 . cells were cultured at high or low density and acutely treated with GA to close all the existing GJ.

The morphological features and the intercellular communication capabilities of BAC cultured at high or low density are illustrated in Fig. 8. Seeded at high density, cells formed almost confluent monolayers ( $e$ and $f$ ). When seeded at low density, cells spread rather homogeneously over the entire surface of the Petri dish ( $a$ and $b$ ) and appeared as single cells or groups of few cells (generally 3 or 4 ). Lucifer yellow microinjected into the cytoplasm of one of these cells diffused to the other cells of the group (Fig. 8, $c$ and $d$ ). Cells cultured at high density were highly coupled through GJ as shown in $g$ and $h$. Cortisol production by BAC cultured under these two conditions was measured in response to increasing concentrations of ACTH, from $0.1 \mathrm{pM}$ to $10 \mathrm{nM}$ (Fig. 9). The concentrationresponse curve obtained with cells cultured at low density was shifted towards the right as compared to that obtained with confluent monolayers. The maximum cortisol production as well as the ACTH concentration required to reach it were similar for BAC cultured at high and low density. It is noteworthy that increasing concentrations of ACTH produced the same gradual 

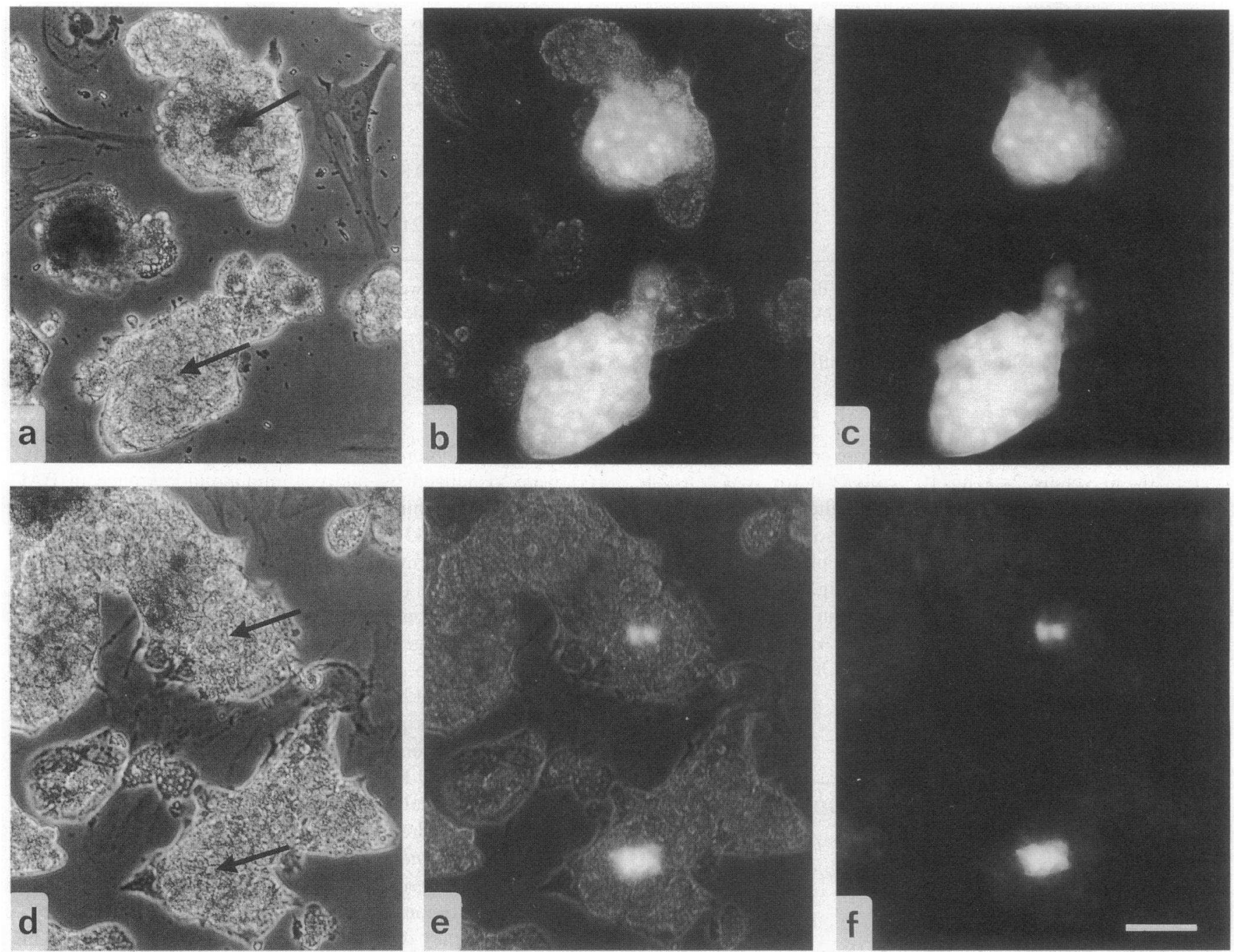

Figure 5. Intercellular communication between HAC in culture. Inhibition of the cell-to-cell diffusion of Lucifer yellow by GA. HAC $\left(2.1 \times 10^{5}\right.$ cells $\left./ \mathrm{cm}^{2}\right)$ were cultured for $5 \mathrm{~d}$ and incubated without $(a-c)$ or with $(d-f) 10 \mu \mathrm{M} \mathrm{GA}$ for $30 \mathrm{~min}$ at $37^{\circ} \mathrm{C}$. Lucifer yellow was microinjected at the surface of cell clusters. Since the cells were round and closely packed, possibly two or three received the fluorescent dye. The sites of injection are indicated by arrows on the phase contrast micrographs. The distribution of the fluorescent probe was examined within 5 min after microinjection. The panels from the left to the right correspond to phase contrast ( $a$ and $d$ ), phase contrast plus fluorescence ( $b$ and $e$ ) and fluorescence ( $c$ and $f$ ) images of the same field. HAC were highly coupled through GJ $(a-c)$, and GA strongly inhibited cell-to-cell communication; the few fluorescent cells found in GA-treated HAC probably correspond to cells which received Lucifer yellow by microinjection. Bar, $50 \mu \mathrm{m}$.

cAMP increase in the two conditions of culture. Results of Fig. 9 also illustrate the well-established discrepancy $(29,36)$ between the ACTH concentrations required for stimulation of cortisol production and ACTH concentrations active on cAMP generation.

If the difference in the responsiveness of BAC cultured at high and low density to ACTH is directly linked to the difference in GJ coupling and therefore to a difference in the ability of cells to exchange informative molecules (here cAMP), one would expect a complete disappearance of this difference by blocking cell-to-cell communication by GA treatment. Results reported in Fig. 10 are in complete agreement with this prediction. The ACTH concentration-response curves obtained with BAC cultured at high or low density and exposed to a 2-h incubation period with $5 \mu \mathrm{M}$ GA (Fig. $10 \mathrm{~B}$ ) were superimposed and shifted towards the right as compared with the doseresponse curves obtained with untreated cells (Fig. $10 \mathrm{~A}$ ). As observed in all the above-mentioned experiments, the maximum responses to ACTH were not altered by the GA treatment. The changes in the responsiveness of BAC to ACTH were quantified by comparing the $\mathrm{ACTH} \mathrm{ED}_{50}$. Average values obtained on three different cell preparations are reported on Table II. Preventing highly coupled BAC (that is, BAC cultured at high density) from communicating by GA treatment resulted in a 25-fold increase in the ACTH $\mathrm{ED}_{50}$.

\section{Discussion}

In this study we have used adrenal cortical cells, which remain fully differentiated in primary culture, as a model system to demonstrate that the responsiveness of a cell population to an external signal, such as a polypeptide hormone, is dependent on the intercellular communication determined by the level of cell-to-cell coupling mediated by GJ. Adrenal cortical cells of 


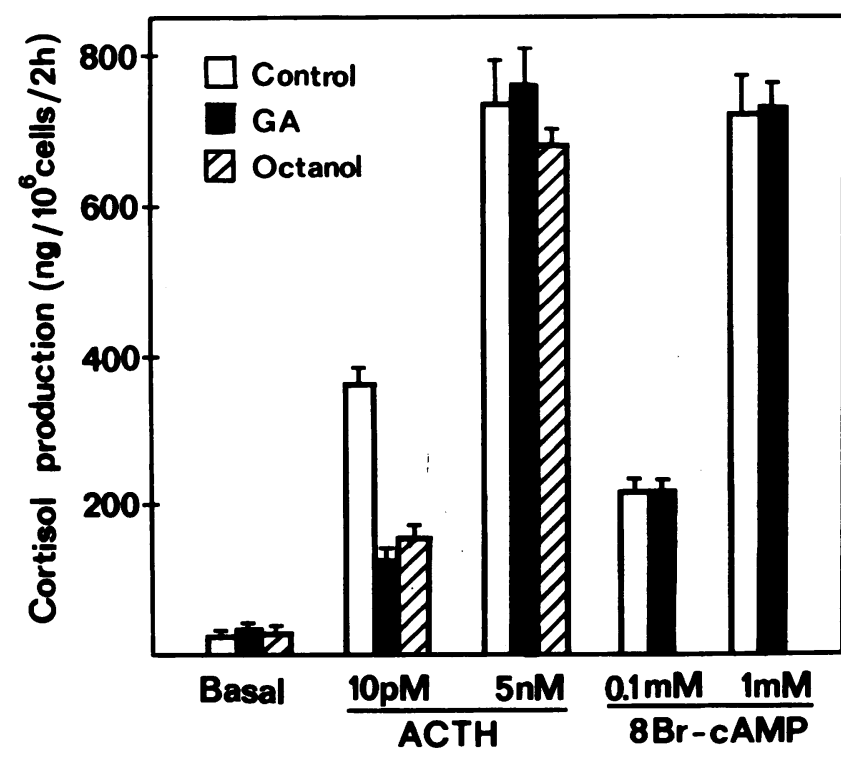

Figure 6. Incidence of the inhibition of GJ-mediated intercellular communication on ACTH-stimulated cortisol production by HAC. HAC $\left(2.1 \times 10^{5} \mathrm{cells} / \mathrm{cm}^{2}\right)$ cultured for $5 \mathrm{~d}$ were incubated without or with ACTH ( $10 \mathrm{pM}$ or $5 \mathrm{nM})$ or $8 \mathrm{Br}$-cAMP $(0.1$ or $1 \mathrm{mM})$ in the absence or the presence of $5 \mu \mathrm{M} \mathrm{GA}$ or $1 \mathrm{mM}$ octanol for $2 \mathrm{~h}$ at $37^{\circ} \mathrm{C}$. Cortisol was assayed in the medium. Results are the mean \pm SEM of the values obtained in two separate experiments; each experimental condition was done in quadruplicate. Both GA and octanol decreased the response to the submaximal concentration of $\mathrm{ACTH}$.

bovine or human origin in primary culture possess GJ, the functional state of which was measured by analysis of the cell-tocell transfer of the fluorescent dye: Lucifer yellow. Most of the cells were capable of communicating with many of their neighbors. However, $\sim 20 \%$ of cells, especially in cultured BAC, were uncoupled as measured by the microinjection assay. A similar observation has been made on another type of endocrine cells in primary culture: thyroid epithelial cells (37). The cells which do not exchange low molecular mass substances with their neighbors could either be devoid of GJ or could have their GJ channels in a closed conformation. The latter hypothesis is more likely since it has been possible to convert such a sub-population of uncoupled thyroid cells into communicating cells by a short-term hormone treatment (37). BAC and HAC in primary culture possess GJ composed of connexin 43 , alternatively referred to as $\alpha_{1}$ connexin (38). This is in agreement with a recent report (39) showing that rat adrenal glands express connexin 43 but no connexin 32 . Since many cell types express more than one connexin (40-43), one cannot exclude the presence of GJ formed by other connexins. The GJ inhibitor, $18 \alpha$-glycyrrhetinic acid or GA, originally described by Davidson and his colleagues (21) was found remarkably potent on adrenal cortical cells. GA has been preferred to the more common GJ inhibitor, octanol, since GA completely inhibits GJ-mediated intercellular communication in the micromolar concentration range whereas millimolar concentrations of octanol are required. Furthermore, GA at a concentration of $5 \mu \mathrm{M}$ had no detectable effect on cell morphology and did not modify any of the metabolic parameters tested: hormone binding, hormone-activation of adenylyl cyclase and maximum cortisol production. Due to its lipophilic properties, GA may insert into the

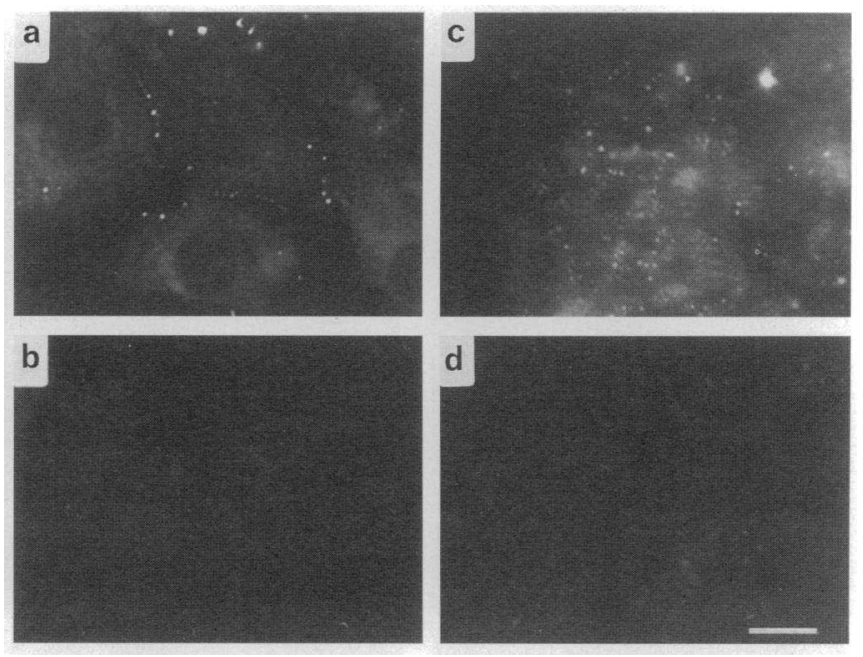

Figure 7. Immunodectection of connexin 43 in $\mathrm{BAC}$ and $\mathrm{HAC}$ in primary culture. BAC and HAC $\left(2 \times 10^{5}\right.$ cells $\left./ \mathrm{cm}^{2}\right)$ cultured for $5 \mathrm{~d}$ were fixed and permeabilized as indicated in "Experimental procedures." Fixed BAC ( $a$ and $b$ ) and HAC ( $c$ and $d$ ) were incubated with either the affinity-purified anti-connexin 43 antibodies ( $a$ and $c$ ) or the corresponding fraction of the preimmune serum $(b$ and $d)$. Immune complexes were detected using anti-rabbit IgG antibody conjugated to fluorescein. Bar, $50 \mu \mathrm{m}$.

plasma membrane and interact with GJ protein oligomers, the connexons, and thereby induce a conformational change causing closure of GJ channels (22)

When the concentration of ACTH is sub-maximal, GA-induced GJ closure produces a concentration-dependent inhibition of ACTH-stimulated cortisol production. This finding indicates that the action of ACTH at low concentration necessitates a GJ-mediated cell-to-cell transfer of cytoplasmic molecule(s). ACTH is known to regulate adrenocortical cell activities such as cortisol production by the activation of adenylyl cyclase and the generation of cAMP as the intracellular messenger $(19,20)$. Hence, it is reasonable to postulate that the signaling molecule in question is cAMP. The cell-to-cell transfer of cAMP appears to be operative in other cell types (16-18) and could represent the limiting step in the action of low ACTH concentrations on adrenal cells. At low hormone concentrations, only a fraction of the cell population would respond by an increase of intracellular cAMP. If GJ are closed, only these cells would be engaged in steroid production. If cell-to-cell communication is possible, cAMP would be transferred to neighboring cells and therefore more cells would be activated and participate in hormone production. The number of recruited cells is expected to depend not only on the number of cells which communicate with the responder cells, but also on the amounts of cAMP produced by these cells and the diffusion and dilution of the nucleotide. After ACTH stimulation of adrenal cells, maximal intracellular cAMP content has been observed within $15-20 \mathrm{~min}(29,36)$. Thereafter, it remains stable or slightly decreases, whereas the extracellular cAMP progressively increases for at least $60 \mathrm{~min}$, indicating continuous cAMP production. At $15 \mathrm{~min}$, the cAMP content of cells treated with $10 \mathrm{pM}$ or $1 \mathrm{nM}$ ACTH was $\sim 3$ pmoles/ $10^{6}$ cells and 20 pmoles $/ 10^{6}$ cells, respectively $(29,36$, and our own unpublished results). Considering that the diameter of $\mathrm{BAC}$ is $\sim 16 \mu \mathrm{m}$, one can calculate that cAMP would reach, if uniformly distributed in the total cell volume, a concentration 

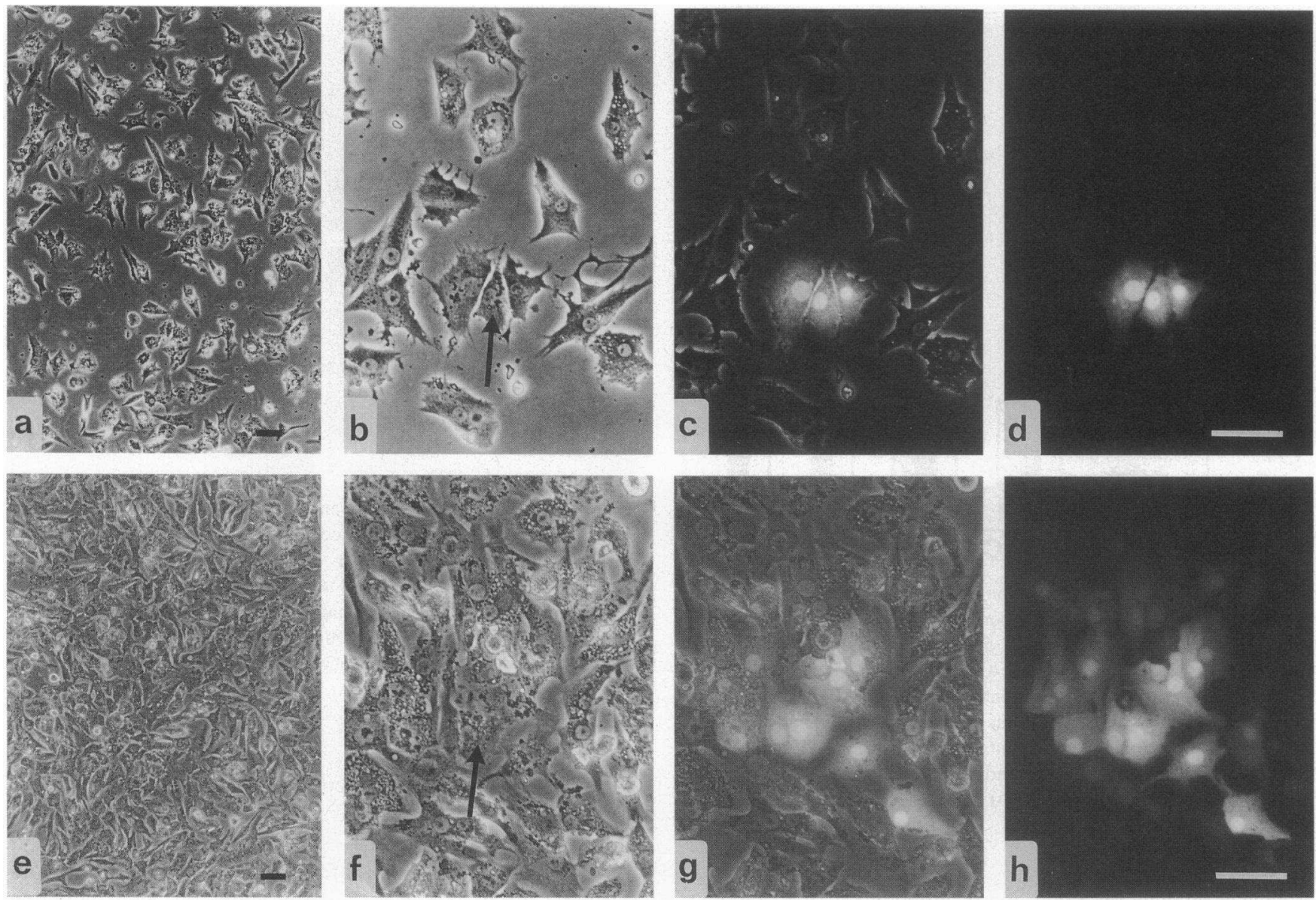

Figure 8. Level of GJ-mediated intercellular communication in BAC cultured at high or low density. BAC were cultured for 5 days at a density of $0.24 \times 10^{5}(a-d)$ or $2.4 \times 10^{5}(e-h)$ cells $/ \mathrm{cm}^{2}$. The difference in the cell organization is illustrated in the low magnification phase contrast micrographs of $a$ and $e$. Cells identified by arrows in $b$ and $f$ were microinjected with Lucifer yellow. The fluorescent probe largely diffused in a large number of adjacent cells in high density cultured BAC ( $g$ and $h$ ) whereas its diffusion among cells cultured at low density was clearly limited by the number of cells in contact with the injected one $(c$ and $d)$. The phase contrast image $(b)$ and the fluorescence image $(d)$ are superimposed in $c$. The same is true for $f$ and $h$ which give $g$. Bar, $50 \mu \mathrm{m}$.

of 1 and $10 \mu \mathrm{M}$, respectively. These concentrations appear to be one or two orders of magnitude higher than the cAMP concentration required for a half-maximal activation of cAMPdependent protein kinase in cytosolic extracts from adrenal cells $(44,45)$. Thus, diffusion of the nucleotide to 10 to 20 neighboring cells through $\mathrm{GJ}$ could theoretically activate the protein kinase $\mathrm{A}$ of these cells. These calculations are rough estimates since they do not take into consideration the true intracellular distribution of the nucleotide and the amounts of cAMP that are degraded or leave the cells. However, they are consistent with the observations of Fletcher and Greenan (18) showing that the increased cAMP production by a single cell was able to activate protein kinase A of several neighboring cells which communicated through GJ. The interpretation of the effects of GA on the response of either BAC or HAC to sub-maximal concentrations of ACTH, based on an inhibition of the diffusion of cAMP between responder and non-responder cells coupled via GJ, is strengthened by two distinct experimental observations. First, the cell responses to maximal ACTH concentrations were never affected by blocking GJ-mediated intercellular communication. This indicates that each cell within the cell population, whatever its intrinsic sensitivity to ACTH, is capable of responding to elevated concentrations of the hormone by increasing its intracellular cAMP concentration and therefore the cortisol production. Under these conditions, cyclic AMP diffusion between coupled cells is not necessary and GJ communication can be inhibited without influencing the overall hormone response of the cell population. Second, the steroidogenic response of isolated BAC in suspension (dispersed by mild trypsin treatment) to a submaximal ACTH concentration was not altered by GA. As a consequence of the disruption of GJ, cells behave as separate units with their own responsiveness to the hormone.

It is generally believed that the dose-response curves obtained with a hormone acting through membrane receptors is due either to the activation of an increasing number of cells when the concentration of the agonist increases (threshold response model) or to a progressive activation of each cell in response to increasing concentrations of the agonist (graded response model) (46). In the first model, the threshold concentration of agonist necessary to initiate the response differs among individual cells. This all-or-none response suggests a quantal process of response. A threshold concentration to induce an increase of intracellular $\mathrm{Ca}^{2+}$ has been observed in many 


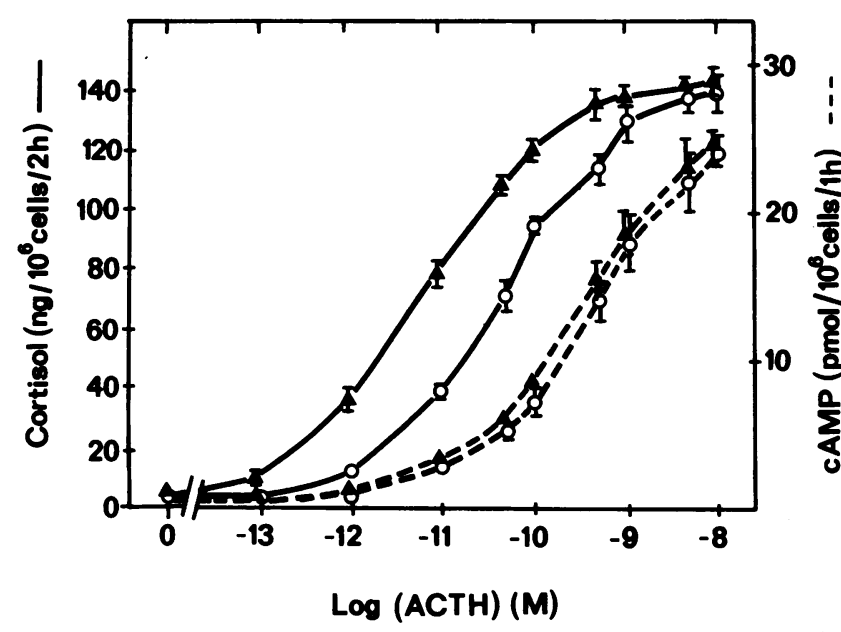

Figure 9. ACTH concentration-response curves for cortisol and cAMP production by BAC cultured at high or low density. BAC at a density of $2.4 \times 10^{5}(\Delta)$ or $0.23 \times 10^{5}(\mathrm{O})$ cells $/ \mathrm{cm}^{2}$ were incubated with increasing concentrations of ACTH. Cortisol and cAMP were measured after 2 and $1 \mathrm{~h}$ of incubation, respectively. Results are expressed as the mean \pm SEM of quadruplicate of a representative experiment. BAC cultured at high or low density exhibited the same maximum capacity to produce cortisol in response to elevated ACTH concentrations but gave very different cortisol production in response to sub-maximal ACTH concentrations; a fact illustrated by the distance between the ACTH dose-response curves (continuous lines). Increasing concentrations of ACTH induced the same gradual increase in cAMP production on BAC cultured at high or low density (dashed lines).

cell types (46-50). A threshold concentration has also been observed in the secretory response of pituitary cells to several peptides $(46,50,51)$. At present, no information exists concerning the type of response of adrenal fasciculata cells to corticotropin, but the response of intercellular $\mathrm{Ca}^{2+}$ in adrenal glomerulosa cells to angiotensin-II follows the threshold model (48, 49). Recent results dealing with another steroidogenic cell type, rat Leydig cells, indicate that the response induced by human chorionic gonadotropin fits with the threshold model (52). Our data give clear indications on the type of response (threshold versus graded) of adrenocortical cells to ACTH. If the response of adrenocortical cells to ACTH was of the graded type, one would not expect an inhibition of the response by blocking GJmediated intercellular communication. In contrast, a response of the threshold type in association with the intercellular communication fits well with the observed results.

To our knowledge, we demonstrate for the first time that GJmediated intercellular communication has a major functional impact on the response of a cell population to non-saturating concentrations of an external signal. We show that, depending on the level of cell-to-cell communication, the hormone concentration required for half-maximal response of the cell population varied up to 25 -fold. The $\mathrm{ACTH} \mathrm{ED}_{50}$, which was equal to 8 pM on BAC cultured at high density, increased to $220 \mathrm{pM}$ when the same cells were prevented from communicating. The $\mathrm{ED}_{50}$ values obtained with GA-treated cells are comparable with those reported in the literature for isolated adrenal cells from various species $(29,53-55)$.

Our findings may provide an explanation for certain pathophysiological observations. The $K_{\mathrm{d}}$ of ACTH for its adrenal receptor in several species $(31,56-58)$ including human (59)
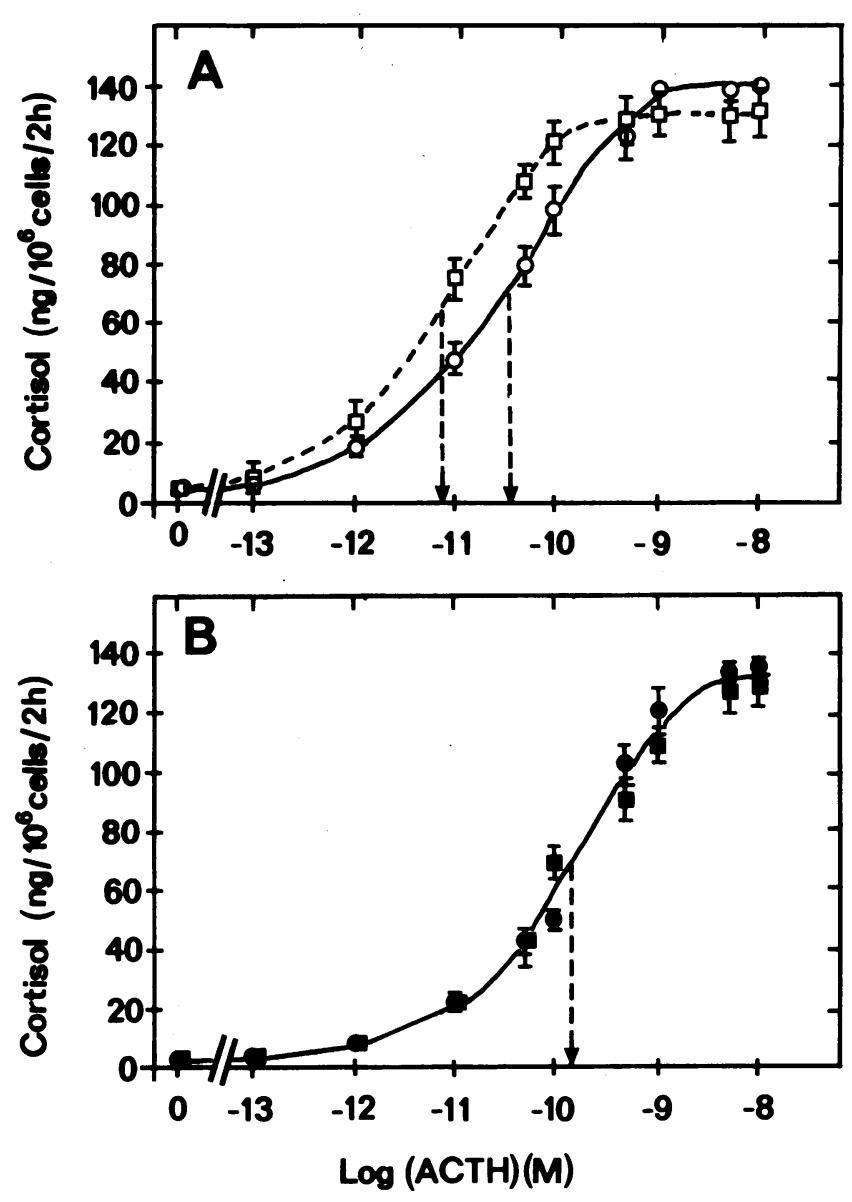

Figure 10. Evidence that GJ-mediated intercellular communication regulates the responsiveness of BAC to submaximal ACTH concentrations. BAC cultured at high $\left(2.4 \times 10^{5} \mathrm{cells} / \mathrm{cm}^{2}\right)(\square, \square)$ or low $\left(0.24 \times 10^{5}\right.$ cells $\left./ \mathrm{cm}^{2}\right)(O, \bullet)$ density for $5 \mathrm{~d}$ were incubated with increasing concentrations of ACTH in the absence $(\square, O)$ or in the presence $(\square, \bullet)$ of 5 $\mu \mathrm{M}$ GA. Cortisol production was measured after $2 \mathrm{~h}$ of incubation. For the clarity of the figure, dose-response curves obtained with untreated BAC are presented in $A$ and those obtained with GA-treated BAC are presented in $B$. Results are expressed as the mean \pm SEM of the values obtained on three distinct cell preparations. The vertical dashed lines allow appreciation of the difference in the ACTH concentration that caused the half-maximal cortisol production in each experimental condition. When treated by GA, BAC cultured at either high or low density exhibited the same sensitivity to ACTH.

is about $0.5-1 \mathrm{nM}$. However, in humans, under physiological conditions, plasma ACTH concentrations are very low, less than $5 \mathrm{pM}$, and an 8-10-fold increase (to $40-50 \mathrm{pM}$ ) is known to induce almost maximum acute cortisol secretion $(25,26)$. Similarly, plasma cortisol levels are very high in many patients with Cushing's disease, despite the fact that plasma ACTH concentrations are between 50 and $100 \mathrm{pM}$ (27). Thus, in this range of ACTH concentration, the functional state of GJ and therefore the level of cell-to-cell communication could be of major importance in determining the amplitude of the overall response of the gland. Finally, the present work establishes that human and bovine adrenal cells are coupled via GJ and that GJ-mediated cell-to-cell communication enhances the responsiveness to low ACTH concentrations. These data might be of general significance and apply to many cell types, because GJ 
Table II. The Responsiveness of BAC to ACTH Depends on the Level of GJ-mediated Intercellular Communication

\begin{tabular}{lccc}
\hline & \multicolumn{2}{c}{$\mathrm{ACTH}_{\text {ED }}\left(\times 10^{10} \mathrm{M}\right)$} & \\
\cline { 2 - 3 } Culture conditions & Control & $\mathrm{GA}(5 \mu \mathrm{M})$ & $\begin{array}{c}\text { GA-induced ACTH } \\
\mathrm{ED}_{50} \text { increase }\end{array}$ \\
\hline Low cell density & $0.45 \pm 0.14$ & $2.5 \pm 1.2^{\ddagger}$ & $\times 5.5$ \\
High cell density & $0.085 \pm 0.013^{*}$ & $2.2 \pm 0.9^{\ddagger}$ & $\times 25.8$ \\
\hline
\end{tabular}

Effects of GA on $\mathrm{ACTH} \mathrm{ED}_{50}$ for cortisol production by BAC cultured at low or high density. Experimental conditions are the same as those described in Fig. 10. Results are expressed as the mean \pm SEM of the values obtained on three separate cell preparations. Statistical analysis was performed by the Student paired $t$ test.

* Significant difference $(P<0.05)$ with the value of the same column

${ }^{\ddagger}$ Significant difference $(P<0.05)$ with the value of the same line.

are widespread structures and most cells are under control of regulatory signals acting through plasma membrane receptors and intracellular messengers which can diffuse from cell-to-cell via GJ.

\section{Acknowledgments}

The authors thank Professor D. Gros (UA CNRS 179, Marseille) for the supply of anti-connexin antibodies and to D. Langlois, A. Penhoat and $C$. Jaillard for their help in the preparation of bovine adrenal cells. M.C. Lebrethon was supported by a fellowship from "La Fondation pour la Recherche Médicale" (France).

\section{References}

1. Loewenstein, W. R. 1981. Junctional intercellular communication : the cellto-cell membrane channel. Physiol. Rev. 61:829-913.

2. Beyer, E. C., D. L. Paul, and D. A. Goodenough. 1990. Connexin family of gap junction proteins. J. Membr. Biol. 116:187-194.

3. Loewenstein, W. R. 1979. Junctional intercellular communication and the control of growth. Biochim. Biophys. Acta. 560:1-65.

4. Zhu, D., G. M. Kidder, S. Caveney, and C. C. G. Naus. 1992. Growth retardation in glioma cells cocultured with cells overexpressing a gap junction protein. Proc. Natl. Acad. Sci. USA. 89:10218-10221.

5. Holder, J. W., E. Elmore, and J. C. Barrett. 1993. Gap junction function and cancer. Cancer Res. 53: 3475-3485.

6. Trosko, J. E., B. V. Madhukar, and C. C. Chang. 1993. Endogenous and exogenous modification of gap junctional intercellular communication : toxicological and pharmacological implications. Life Sci. 53:1-19.

7. Stagg, R. B., and W. H. Fletcher. 1990 . The hormone-induced regulation of contact-dependent cell-cell communication by phosphorylation. Endocr. Rev. 11:302-325.

8. Saez, J. C., V. M. Berthoud, A. P. Moreno, and D. C. Spray. 1993. Multiplicity of controls in differentiated and undifferentiated cells and possible functiona implications. In Advances in Second Messenger and Phosphoprotein Research. S. Shenoliras and A. C. Naizy, editors. Raven Press Ltd. New York. 27:163178.

9. Saez, J. C., J. A. Connor, D. C. Spray, and M. V. L. Bennett. 1989 Hepatocyte gap junctions are permeable to the second messenger, inositol 1,4 5-triphosphate, and to calcium ions. Proc. Natl. Acad. Sci. USA. 86:2708-2712.

10. Charles, A. C., C. C. G. Naus, D. Zhu, G. M. Kidder, E. R. Dirksen, and M. J. Sanderson. 1992. Intercellular calcium signaling via gap junctions in glioma cells. J.Cell Biol. 118:195-201.

11. Sandberg, K., H. Ji, T. Iida, and K. J. Catt. 1992. Intercellular communication between follicular angiotensin receptors and Xenopus Laevis oocytes : mediation by an inositol 1, 4, 5-trisphosphate-dependent mechanism. J. Cell Biol. 117:157-167.

12. Christ, G. J., A. P. Moreno, A. Melman, and D. C. Spray. 1992. Gap junction-mediated intercellular diffusion of $\mathrm{Ca}^{++}$in cultured human corporal smooth muscle cells. Am. J. Physiol. 263:C373-C383.

13. Boitano, S., E. R. Dirksen, and M. J. Sanderson. 1992. Intercellular propagation of calcium waves mediated by inositol trisphosphate. Science (Wash. DC). 258:292-295.
14. Osipchuk, Y., and M. Cahalan. 1992. Cell-to-cell spread of calcium-signals mediated by ATP receptors in mast cells. Nature (Lond.). 359: 241-244.

15. Tsien, R. W., and R. Weingart. 1976. Inotropic effect of cyclic AMP in calf ventricular muscle studied by a cut end method. J. Physiol. 260:117-141.

16. Lawrence, T. S., W. H. Beers, and N. B. Gilula. 1978. Transmission of hormonal stimulation by cell-to-cell communication. Nature (Lond.). 272:501506.

17. Murray, S. A., and W. H. Fletcher. 1984. Hormone-induced intercellular signal transfer dissociates cyclic AMP-dependent protein kinase. J. Cell Biol. 98:1710-1719.

18. Fletcher, W. H., and J. R. T. Greenan. 1985. Receptor mediated action without receptor occupancy. Endocrinology. 114:1660-1662.

19. Saez, J. M., A. M. Morera, and A. Dazord. 1981. Mediations of the effects of ACTH on adrenal cells. Adv. Cyclic Nucleotide Res. 14:563-578.

20. Schimmer, B. P. 1980. Cyclic nucleotides in hormonal regulation of adrenocortical function. Adv. Cyclic Nucleotide Res. 13:181-214.

21. Davidson, J. S., I. M. Baumgarten, and E. H. Harley. 1986. Reversible inhibition of intercellular junctional communication by glycyrrhetinic acid. Biochem. Biophys. Res. Commun. 134:29-36.

22. Davidson, J. S., and I. M. Baumgarten. 1988. Glycyrrhetinic acid derivatives : a novel class of inhibitors of gap-junctional intercellular communication. Structure-activity relationships. J. Pharmacol. Exp. Ther. 246:1104-1107.

23. Spray, D. C., and J. M. Burt. 1990. Structure-activity relations of the cardiac gap junction channel. Am. J. Physiol. 258:C195-C205.

24. Meda, P., D. Bosco, M. Chanson, E. Giordano, L. Vallar., C. Wollheim, and L. Orci. 1990. Rapid and reversible secretion changes during uncoupling of rat insulin-producing cells. J. Clin. Invest. 86:759-768.

25. Gallagher, T. F., K. Yoshida, H. D. Roffwarg, D. K. Fukushima, E. D. Weitzman, and L. Hellman. 1973. ACTH and cortisol secretory in man. J. Clin. Endocrinol. Metab. 36:1058-1068.

26. Crowley, S., P. Hindmarsh, P. Holonnia, J. W. Honour, and C. G. D. Brook. 1991. The use of low doses of ACTH in the investigation of adrenal function in man. J. Endocrinol. 130:475-479.

27. Baxter, J. D., and J. B. Tyrel. 1986. The adrenal cortex. In Endocrinology and Metabolism (2nd edition). P. Felig, J.D. Baxter, A.E. Broadus, and L.A Frohman, editors. Mc Graw-Hill. New York. 511-692.

28. Penhoat, A., C. Jaillard, A. Crozat, and J. M. Saez. 1988. Regulation of angiotensin-II receptors and steroidogenic responsiveness in cultured bovine fasciculata and glomerulosa adrenal cells. Eur. J. Biochem. 172:247-254.

29. Saez, J. M., D. Evain, and D. Gallet. 1978. Role of cyclic AMP and protein kinase on the steroidogenic action of ACTH, prostaglandin $E_{1}$ and dibutyryl cyclic AMP in normal adrenal cells and adrenal tumor cells from humans. J. Cyclic Nucleotide Res. 4:311-321.

30. Rainey, W. E., I. Viard, J. I. Mason, C. Cochet, E. M. Chambaz, and J. M Saez. 1988. Effects of transforming growth factor beta on ovine adrenocortical cells. Mol. Cell. Endocrinol. 60:189-198.

31. Penhoat, A., C. Jaillard, and J. M. Saez. 1989. Corticotropin positively regulates its own receptors and cAMP responses in cultured bovine adrenal cells. Proc. Natl. Acad. Sci. USA. 86:4978-4981.

32. Viard, I., W. E. Rainey, A. M. Capponi, M. Begeot, and J. M. Saez. 1990. Ovine Adrenal fasciculata cells contain angiotensin-II receptors coupled to intracellular effectors but are resistant to the steroidogenic effects of this hormone. Endocrinology. 127:2071-2078.

33. Stewart, W. W. 1978. Functional connections between cells revealed by dye-coupling with a highly fluorescent naphtalimide tracer. Cell. 14:741-759.

34. Mazet, J. L., T. Jarry, D. Gros, and F. Mazet. 1992. Voltage dependence of liver gap-junction channels reconstituted into liposomes and incorporated into planar bilayers. Eur. J. Biochem. 210:249-256.

35. El Aoumari, A., C. Fromaget, E. Dupont, H. Reggio, P. Durbec, J.P. Briand, K. Boller, B. Kreitman, and D. Gros. 1990. Conservation of a cytoplasmic carboxy-terminal domain of connexin 43 , a gap junctional protein in mammal heart and brain. J. Membr. Biol. 115:229-240.

36. Sala, G. B., K. Hayashi, K. J. Catt, and M. L. Dufau. 1979. Adrenocorticotropin action in isolated adrenal cells. J. Biol. Chem. 254:3861-3865.

37. Munari-Silem, Y., C. Audebet, and B. Rousset. 1991. Hormonal control of cell-to-cell communication : regulation by thyrotropin of the gap junctionmediated dye transfer between thyroid cells. Endocrinology. 128:3299-3309.

38.Kumar, N. M., and N. B. Gilula. 1992. Molecular biology and genetics of gap junction channels. Seminars in Cell Biology. 3:3-16.

39. Meda, P., M. S. Pepper, O. Traub, K. Willecke, D. Gros, E. Beyer, B. Nicholson, D. Paul, and L. Orci. 1993. Differential expression of gap junction connexins in endocrine and exocrine glands. Endocrinology. 133: 2371-2378.

40. Dermietzel, R., T. K. Hwang, and D. S. Spray. 1990. The gap junction family: structure, function and chemistry. Anat. Embryol. 182:517-528.

41. Zhang, J. T., and B. J. Nicholson. 1989. Sequence and tissue distribution of a second protein of hepatic gap junctions, Cx26, as deduced from its cDNA. J. Cell Biol. 109:3391-3401.

42. Traub, O., J. Look, R. Dermietzel, F. Brummer, D. Hulser, and K. Willecke 1989. Comparative characterization of the $21 \mathrm{kD}$ and $26 \mathrm{kD}$ gap junction proteins in murine liver and cultured hepatocytes. J. Cell Biol. 108:1039-1051. 
43. Willecke, K., H. Hennemann, E. Dahl, S. Junggbluth, and R. Heynkes. 1991. The diversity of connexin genes encoding gap junctional proteins. Eur. J. Cell. Biol. 56:1-7.

44. Doherty, P. J., J. Tsao, B. P. Schimmer, M. C. Mumby, and J. A. Beavo 1982. Alteration of regulatory subunit of type 1 cAMP-dependent protein kinase in mutant Y1 adrenal cells resistant to 8-bromoadenosine 3': 5'monophosphate. J. Biol. Chem. 257: 5877-5883.

45. Wong, M., A. J. Krolczyk, and B. P. Schimmer. 1992. The causal relationship between mutations in CAMP-dependent protein kinase and the loss of adrenocorticotropin-regulated adrenocortical functions. Mol. Endocrinol. 6:1614-1624.

46. Canny, B. J., L. G. Jia, and D. A. Leong. 1992. Corticotropin-releasing factor, but not arginine vasopressin, stimulates concentration-dependent increase in ACTH secretion from a single corticotrope. J. Biol. Chem. 267:8325-8329.

47. Cornell-Bell, A. H., S. M. Finkbeiner, M. S. Cooper, and S. J. Smith 1990. Glutamate induces calcium waves in cultured astrocytes: Long-range glia signaling. Science (Wash. DC). 247:470-473.

48. Johnson, E. I. M., A. M. Capponi, and M. B. Vallotton. 1989. Cytosolic free calcium oscillates in single bovine adrenal glomerulosa cells in response to angiotensin II stimulation. Endocrinology. 122:391-402.

49. Johnson, E. M., J. M. Theler, A. M. Capponi, and M. B. Vallotton 1991. Characterization of oscillations in cytosolic free $\mathrm{Ca}^{2+}$ concentration and measurement of cytosolic $\mathrm{Na}^{+}$concentration changes evoked by angiotensin II and vasopressin in individual rat aortic smooth muscle cells. J. Biol. Chem. 266:12618-12626.

50. Leong, D. A., and M. O. Thorner. 1991. A potential code of luteinizing hormone-releasing hormone-induced calcium ion responses in the regulation of luteinizing hormone secretion among individual gonadotropes. J. Biol. Chem. 266: 9016-9022.
51. Goth, M. I., C. E. Lyons, B. J. Canny, and M. O. Thorner. 1992. Pituitary adenylate cyclase activating polypeptide, growth hormone $(\mathrm{GH})$-releasing peptide and GH-releasing hormone stimulate GH release through distinct pituitary receptors. Endocrinology. 130: 939-944.

52. Pino, A. M., H. Inostroza, and L. E. Valladares. 1992. Detection of testosterone secretion from individual rat Leydig cells. J. Steroid Biochem. Mol. Biol. 41:167-170.

53. Sayers, G., R. J. Beal, and S. Seblig. 1972. Isolated adrenal cells : Adrenocorticotropin hormone, calcium, steroidogenesis and cyclic adenosine monophosphate. Science (Wash. DC). 175:1131-1139.

54. Peytreman, A., W. E Nicholson, R. B. Brown, G. W. Liddle, and J. G. Hardman. 1973. Comparative effects of angiotensin and ACTH on cyclic AMP and steroidogenesis in isolated bovine adrenal cells. J. Clin. Invest. 52:835842.

55. Lambert, F., J. Lammerant, and J. Kolanowski. 1983. The stimulatory effects of corticotropin on cortisol biosynthetic pathway in guinia-pig adrenocortical cells. J. Steroid Biochem. 18:731-735.

56. Buckley, D. I., and J. Ramachandran. 1981. Characterization of corticotropin receptors on adrenocortical cells. Proc. Natl. Acad. Sci. USA. 78:7431-7435.

57. Gallo-Payet, N., and E. Escher. 1985. Adrenocorticotropin receptors in rat adrenal glomerulosa cells. Endocrinology. 117:38-46.

58. Klemcke, H. G., and W. G. Pond. 1991. Porcine adrenal adrenocorticotropic hormone receptors: characterization, changes during neonatal development, and response to a stressor. Endocrinology. 128:2476-2488.

59. Catalano, R. D., L. Stuve, and J. Ramachandran. 1986. Characterization of corticotropin receptors in human adrenocortical cells. J. Clin. Endocrinol. Metab. 62:300-304. 